\title{
EHMTI-0185. "Perceived stress index among school adolescents with primary headaches (tension-type headache or migraine) in Tashkent"
}

\author{
S Gazieva*, ANNA Prokhorova, N Rashidova \\ From 4th European Headache and Migraine Trust International Congress: EHMTIC 2014 \\ Copenhagen, Denmark. 18-21 September 2014
}

\section{Introduction}

Psychosocial stress is one of the most important factors causing migraine and T-TH. Stressors of school environment are expected to be a probable cause of headaches.

The aim of the study is to investigate the susceptibility to stress among adolescents with $\mathrm{T}-\mathrm{TH}$ and migraine.

\section{Material and methods}

A total of 135 students with T-TH including 94 girls and 41 boys, 96 students with migraine including 70 girls and 26 boys, 52 students with migraine and coexisting T-TH including 38 girls and 14 boys, and 240 headache free students including 121 girls and 119 boys, aged 12-17 years, participated in the study. Stress influence was established according to the Rahe Stress Scale of perceived stress.

\section{Results}

The average perceived stress index in the group with T-TH was $27.9 \%$; $30.6 \%$ for girls and $25.1 \%$ for boys, in the group with migraine - $19.1 \%$; $20.6 \%$ for girls and $17.6 \%$ for boys, with migraine and coexisting T-TH $29.5 \%$; $33.5 \%$ for girls and $25.5 \%$ for boys. In headache free patients it was $17.9 \% ; 18.4 \%$ for girls and $17.5 \%$ for boys. The perceived stress index revealed an increase with age of patients, frequency of $\mathrm{T}-\mathrm{TH}$ and number of migraine days.

\section{Conclusions}

Increased vulnerability to stress is present among adolescents with $\mathrm{T}-\mathrm{TH}$ and migraine. The correlation between increased stress level and age, gender and frequency of headache was found.
No conflict of interest.

Published: 18 September 2014

\section{doi:10.1186/1129-2377-15-S1-B8}

Cite this article as: Gazieva et al:: EHMTI-0185. "Perceived stress index among school adolescents with primary headaches (tension-type headache or migraine) in Tashkent". The Journal of Headache and Pain 2014 15(Suppl 1):B8.
Submit your manuscript to a SpringerOpen ${ }^{\circ}$ journal and benefit from:

- Convenient online submission

- Rigorous peer review

- Immediate publication on acceptance

- Open access: articles freely available online

- High visibility within the field

Retaining the copyright to your article

Submit your next manuscript at $>$ springeropen.com 